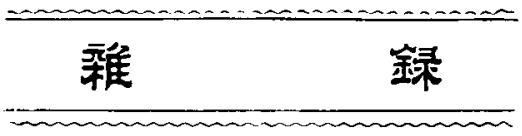

合同製鋼株式會社（獨逸國デユセルトルフ市所在）「スタール、ウント.アイゼン、1927,3， 17 日號所截」

次に揭ぐるは1926年1月14日より9月30日迄の第一回營業年度に對する會社監督部の報告て依て書

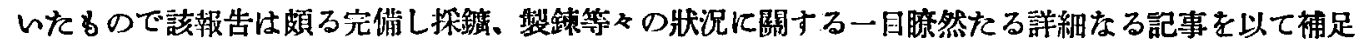
せられて居る。

1925年の夏から秋に及ふ頃 1 偑の意見が强調せられて來た即ちこれは支配的地位を占むる数個の會 社をして結合せしめ而して在來の最善の工場を最經濟的に利用せんが篇に單一の監殞に服する一つの 企業を造ら弓と云ふ意見である。この相談にはラインエルペ、ュニオン、チーセン並にフェニツクス

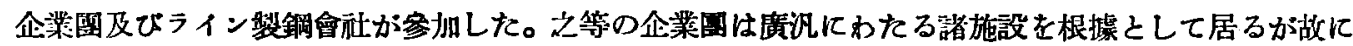
處期の目的の完全なる筫現が允分に保澄せられて居るのであつた。

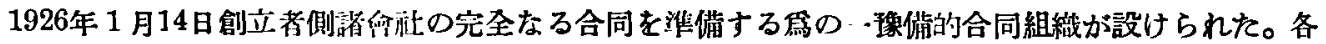
方面にわたる準備はその後數ケ月を經過するらちに相當の進捗を見せたので種々の規約は1926年 5 月

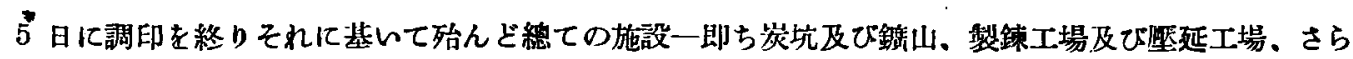

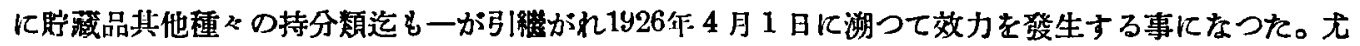
もライン製鋼命社の所有する全炭坑ケルゼン、キルヘシ鏣業秼式會社の所有する獨占炭坑（附屬せる 像詣炭们を包含する）は其他の創立者侧各コンツェルンの少しの土地や-部の工場等と共に特別な理 由から本會蚘に提供せられなかつた。而して資本金は1926胙5月7日の特别總會の決議によつて 8 億 ークと確定せられた。創泣者側諸侖琣の秼式资本の持分は次の如くである。

$$
\text { 金マーク }
$$
1. ラインエルペ、ュニオン
$316,000,000$
2. チーセン企業團
$208,000,000$
3. フェニックス
$208,000,000$
4. ライン慗鎆會社
$68,000,000$
合 計
$800,000,000$

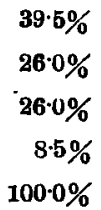

更に 1 億 2,500萬マークのゲヌス、シャイン（ゲヌース、シャイン然とは秼式にあらすして配當を 受くる權利ある證券にしてて分の传先配當を受くるものである）が發行せられ次の如くに分割せられ た。

1. ラインメルパーニオン

$$
\begin{gathered}
\text { ゲヌス、シャイン A } \\
10,000,000
\end{gathered}
$$


2. チーヒン企策菂

3. フメニックス

4. ライン製銅會社

合 㑇
$40,000,000$

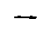

$-$

$50,000,000$
$27,000,000$

$15,000,000$

$7,000,000$

$75,000,000$

1926年7月1日に=ーダーシェルデン、アイヘン、アッテンドルン、ジーゲン、アイゼルン、ワイデ ナウ及びウェルンスベルヒに諸施設を有するシナルロツテ製鍊袾式會社が併合せられた。その熦施設

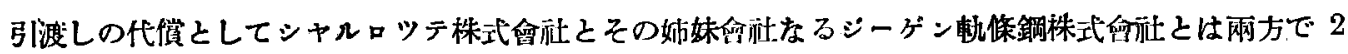
1,000萬マークの株式こ750萬マークBの類のゲヌスシャインを受取つた。

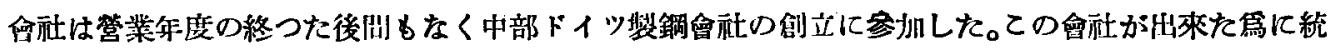

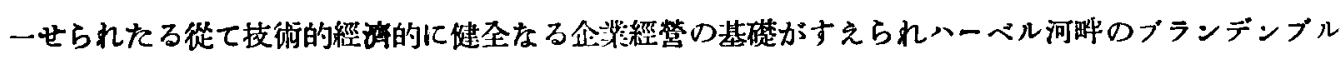

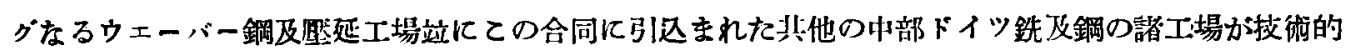
にも經学的にる統一によりて其恩惠に浴するてとになつたのである。

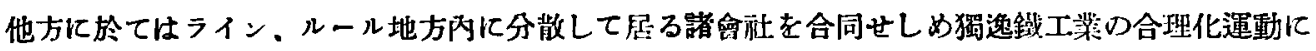

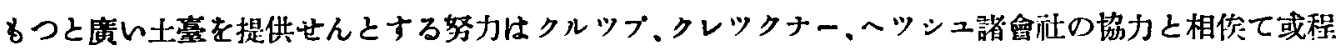

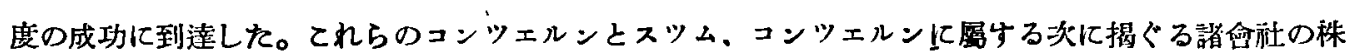

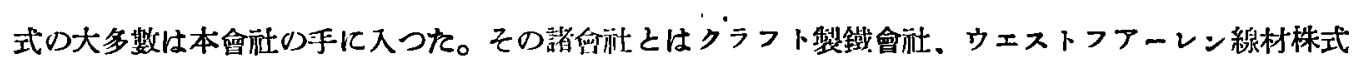

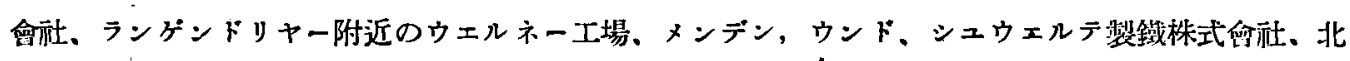

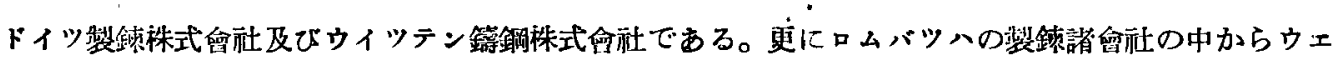
ストフアーレンのボフム製鋼會䎟及びヘンドルフ所在コンコルジアヒュツテの諸事業がレンズブルヒ

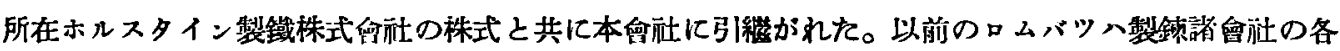

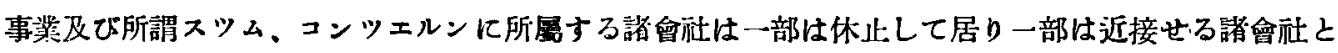
企当共同 Betriebsgemeinschaft を結ぶに至つた。以前にはチーヒン、コンツェルンの重慗なるー部

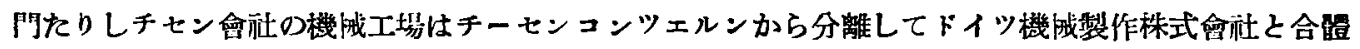

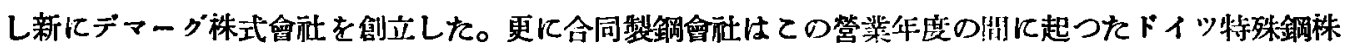

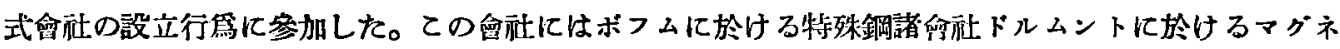
ツト工場が包含せられて居る。

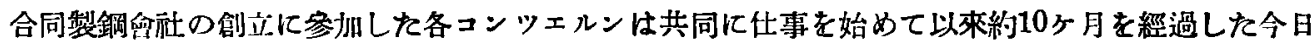

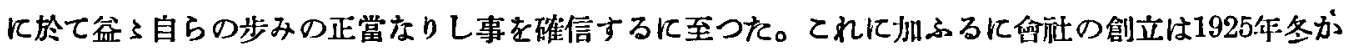

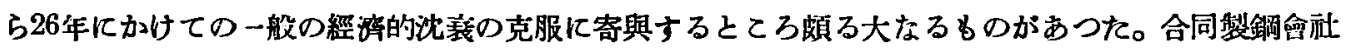
の創立によつて初めて招桃せをれた各㓣立者侧コシッェルン䦌の利害對立の協定が貫行せられた洁果

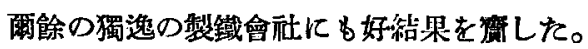

本會㣂の設立は單に倩保件に合併集中を行ふてとは之を避けんとするお針のむとに行はれた各發起 會社は地理的及其他の物的完地から考へて最も有效に綜合せしめられ一箅の監督機關の責任ある指揮 


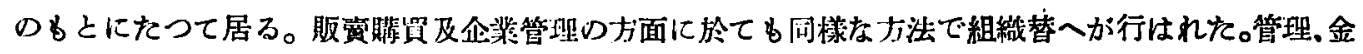

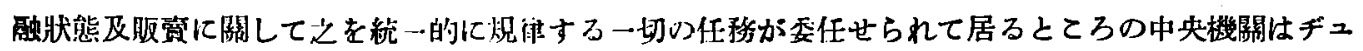

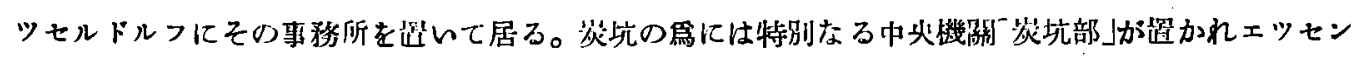

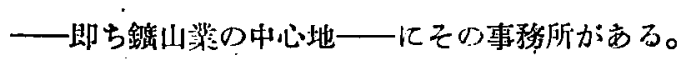

全烮沆は 153 の坑口と 84 の筑所からなり立つて居てドルトムント・ボーフム、ダルセンキルヘン

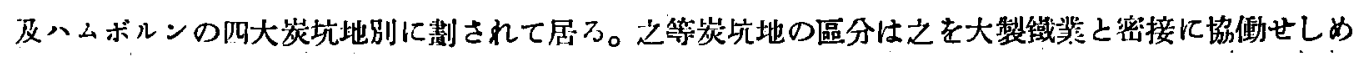

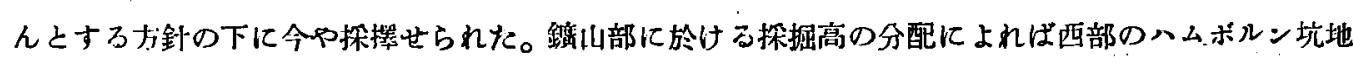
に則しては在來と同様な仕事從て又在來と同栐なる經湾的利用が碓保せられて居る。東部に於てはミ

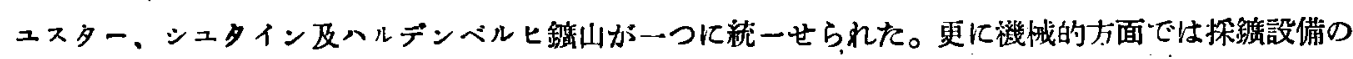

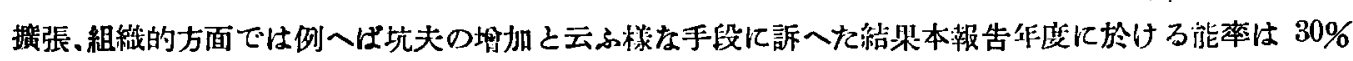
㙁加した。探算のとれない䥀山は休坑して居る。

原料企菲 製戴原料たる石灰及白雲石、粘土及石英の探集場並にジーガーランド、バイエルンの外 スウェーデン・スペイン、ブラジルをる包含する鐵鈸山は共にトルトムントに於ける單一の監督嚾の 下に支配せられて居る。

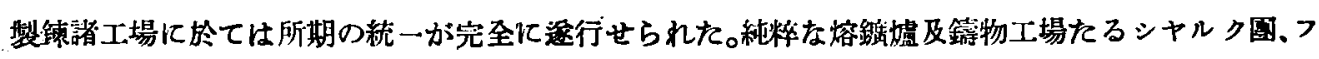

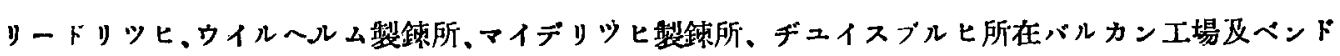
ルク所在コンコルヂア製鍊工場は作業技術の上加ら以下の如くに統一せられた、即ち各箩社に於ては

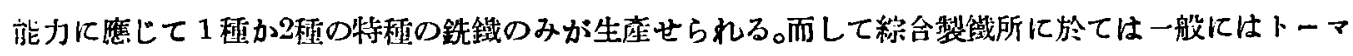

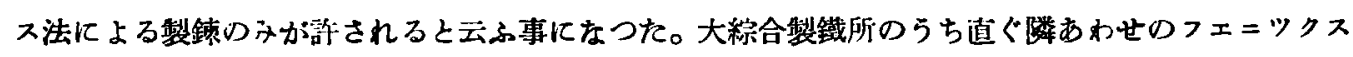
(ルール)とラインスタール(マイデリッヒ)の事篓とは一工場として合體してしまつた。找術統一の見

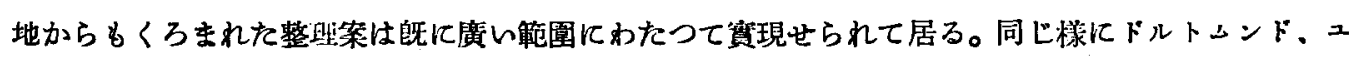
ニオン・ヘルデフェラインは一简の監督の下に統括せられその重椱生産は品純化せられた。一方には漸 次行はれつつする各會㣖の技術的合理化があり他方には高い鐵道運賃を儉約せんとする凡ゆる努力が あるので多くの製銅工場の生產のブログラムは廣い範園にわたつて移動せられるに至つた。原则とし てては外國の注文は可能なる限り輸出に特に便利なラインの各畣社がを引受け一方近所の各種部門の 工蒋人の供給はウェストフアーレンの各會龍が之を司つて居る。而して各會社に對する生產額は次の

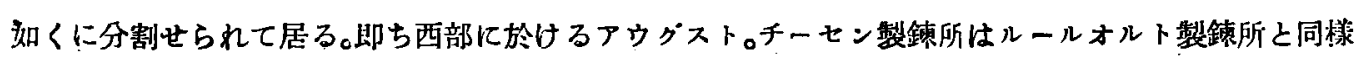
に1月約15萬瀬の鋼塊を生産し一方東部に於ては一つに總括せられだドルトムントールデは丁度 1 月 の生產がゃはり 15 萬顿と定められて居る。ハンボルンのアウグストチーセン製鍊所化於ては（その

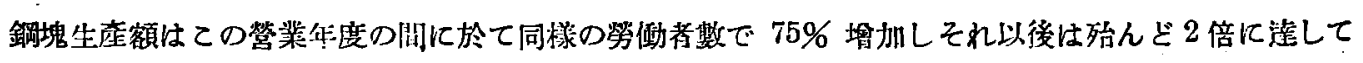

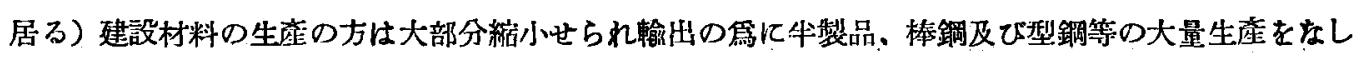
て居る。ルールォルト、マイデリッヒ工場は同樣に外國の注交主として棒鋼や型鋼の注文を能力て應 


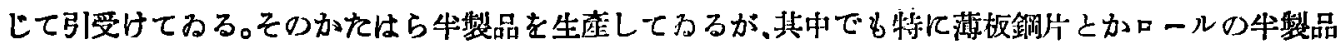
たる鋼片とかの生产を目的としてるる。國內の注文は特にドルトムンドびへルデルに委託されてる

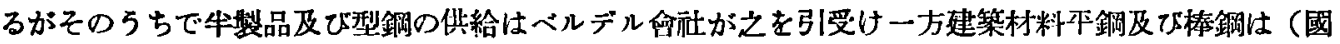
內の需要のため)ドルトムントニニオンが之を生座してるる。その外ドルトムントは积々なる以前と同 樣の生產品即ち橋梁や建筑材料の生產に力を入れてるる。ボフーマー、フェラインは棕合裂鐵所中に 於てもその生産物の種類に於ては特殊を地位を占むるものである。即ちボーフムの各工場は一一ウェ ストフフーレン鋼臷會社はその一つである一以前と同様に主として精良品の生産を委任せられてる るがその設䎜は今迄よりも餘程改良せられて居る。

他方に於ては程々なる加工會社は大㹈鍊各會社が行つたと同じ樣に能ふ限りの經泭的利用を目標と して總括せられ單にプ監督のもとに服するに至つた。鋼管製造恃鋼管工場全部を包含する一企宷團に 統・せられた。同樣に針金や針金製品は主たる工場を入ムに有する特别の企業国に統一せられた。更 にジーガーランドの各工場は其他の蔣板工場と共に特别の企粟圈を形成してみる。以上はその大要の みを記述したものなるも徹底せる事桠の整理の絬果23の非經濟的なりし工場や工場の或部分は必然に 廢止卡られなければならなくなつた。そして之等の工場の製品は能率の高い中心工場が之を引受ける に至つた。

生産品の整理と相侯て今迄の販賞機關全體の整理變革が必要とせられた。最も重要なる䁃延工場の 生产物の販党に關してはその販嘪組合の事務所をデュツセルドルフへ移轉せしむるてとが便利である

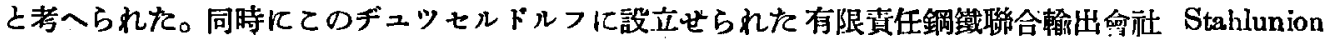
Export G. m. b. h. 一 之は創立者㑡諸會社の關係する國外の組織を基礎として作つたものである 一はこの販党部組合と密接に聯絡をとり乍ら仕事を続けてるる。薄板及びプリキ板の販賣はケルン

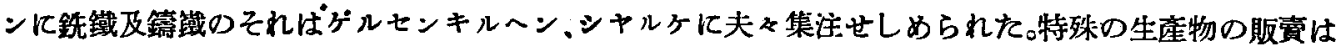
その生產を營む會社にゆだねられてるる。例へばルールォルト。マイデリツヒは市街軦道材料の販嘪を ドルトムント及びボーフム红建設材料の販賣を掌るが如きである。㓣立者側諸會社によつて作られ大 部分はその手中に歸している所の諸商業組合はその活動範園が互に交錯していたので兹にも廣い範園 にかたる集力が必要とせられた。そしてそれは本營業年度に於ては全體から見て必要でない組合を廢 止することによつて䁈現せられた。活動範圍は次の如く即ちトルトムント市ハインリッヒ、アウグス ト、シュルテ會酒は西部及北西部、ベルリン市チーセン鐵鋼株式俞社は北部及び東部(フランクフル トマンハイム市) チーセン・ラインスタール會社は市場の南部を受持つと云ふが如くに區劃づけられ 店石炭副産物の取引注それが組合の手にて行はれざる限りラーブカルへル會社只一つによつて行は れてるる。

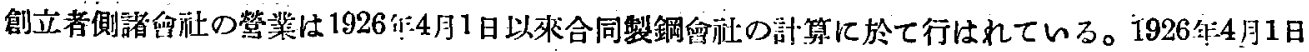

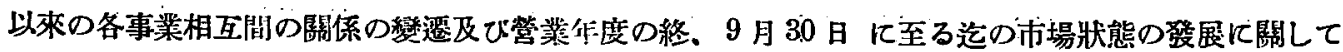


我々は更に献告草より次の點を抄䟿する。

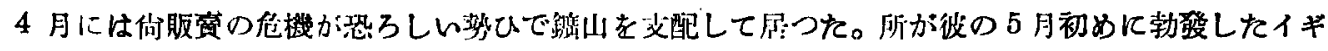

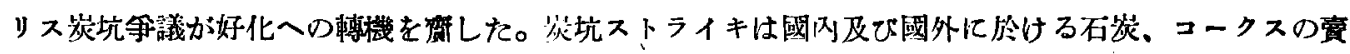

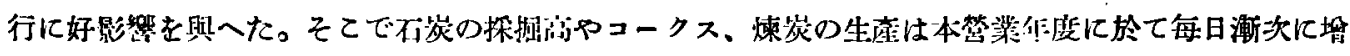

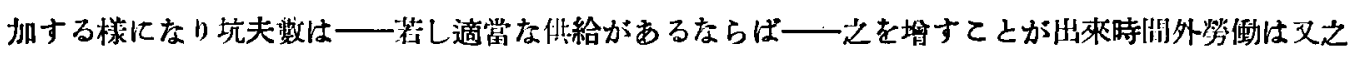

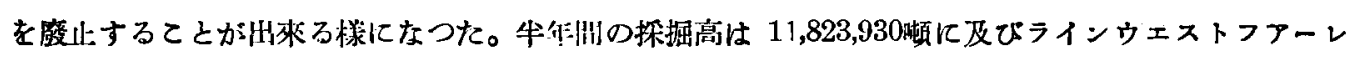

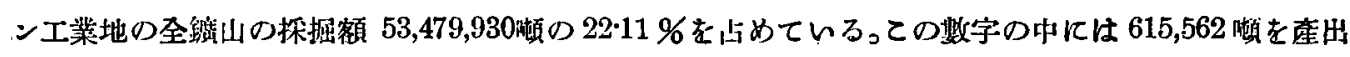

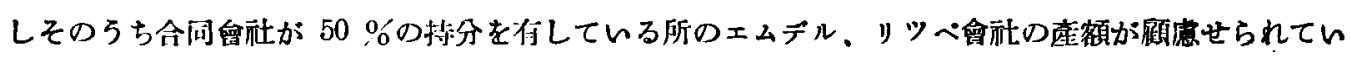
ない。

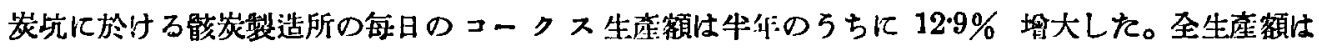
2,737,967瀬に_上つた。整鐵所に於けるコークスの生產は本報告年度中に於て329,964獺である。

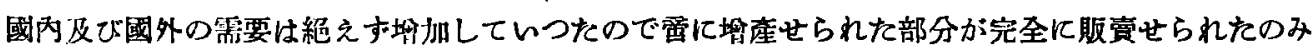

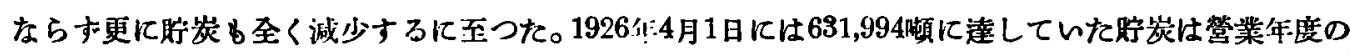

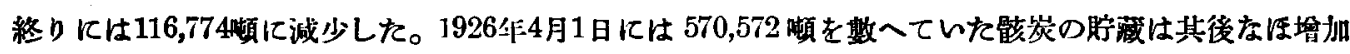

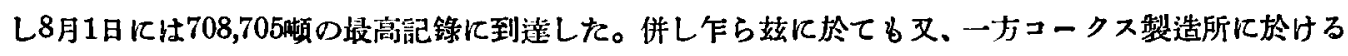
生産制限の筫行によろ緩和があり他方大量の石炭の输出があつたので此の二つの事情は、ナばらしく 㺟大しつつあるコークスの需要と相渎て 8月9月の兩月に於て聍藏部分の5ち213,423噸の皘出を可能

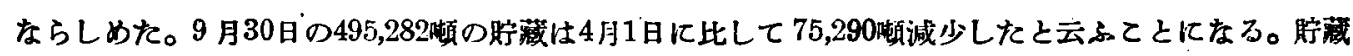
の堿少は營業年度い終の頃は益々激しくなりつつるる。

副产物も亦相富な值段で販路を罗出しているが特にコールタール製品の需娎が激しかつた。只アム モニアの需要が少なかつたので何時も夏期に於てそ5である样に眝藏が垤少した。ベンッールは今も 昔と同樣に不足を告げて居る。

ラインウエストフフーレン石炭シンジケートの1华の持分は1926年4月1日に34,787,820噸であつた。

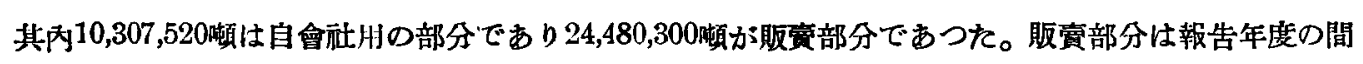

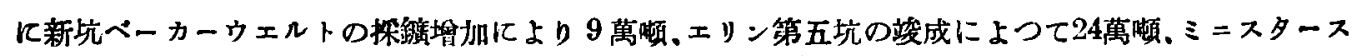

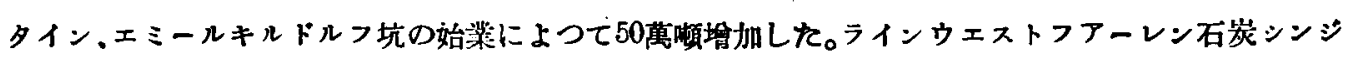

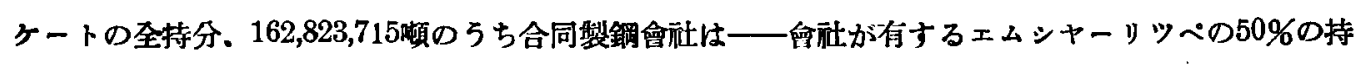
分は之を除外して—1926年10月 1 日に $36,617,820$ 噸即ち $21 \cdot 88 \%$ 所有して居る。

會社に引纕がれた石灰並に白雲石探集地に於ては本營業众度に於もる生產額は生石灰が 296 人の本 均労倬者数にて191,163㖽。白雲石は6,839瀬に達した。

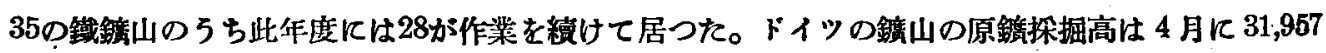
噸で9月に83,356噸に達した。全體で此牛作の間は3,31て人の勞働者で370,941 瀬探掘せられた。 


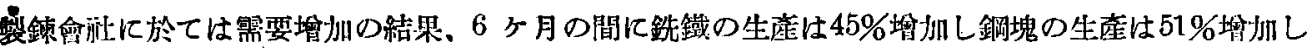

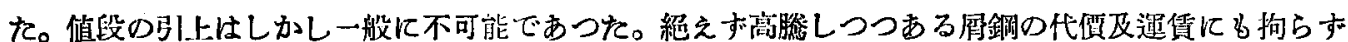
成內に於ては市場を出來るだけ强固にせんと努める必然の結果として值段の引上は斷念せ权ばならな

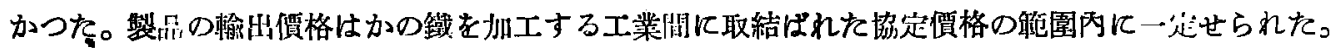
國外に於ても亦西及東の通貨膨脹國の競等は矢㖘值段の引上を不可能にした。フランが泍次良化し安 定するに至つて始めて一一國際鋼塊共同組合の效果と相俟て一一營策作度の終りには鐵の輅出值段が

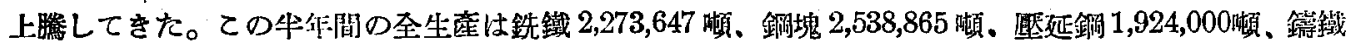
152,116 噸であつた。鐵製品の全製產は（自會社用を除いて）2,203,151 瀬に上りそのうち國队向が $1,259,911$ 噸，國外向が 1,042,240 唃である。

創立者側濯會社が個々の聯合(組合)に對して持つて居る持分は 1926焦4 月1 日を以て本會社に引移 された。重な鐵及鋼の組合に對する全持分は傍采會社に對する持分即ちスツム、ロムバツハ經營に對 する持分等を引くるめて本營業佂度の終には次の表に表はされる。

\begin{tabular}{|c|c|c|c|}
\hline 組 合 & 各䁚社の持分總額 & 合同吿鋼會社の持分 & その\% \\
\hline 銚捈祖合 & $2,268,852$ & 578,802 & 4:3:141 \\
\hline 銅塊組合” & $16,635,365$ & $6,834,101$ & 41.082 \\
\hline \multicolumn{4}{|l|}{ A 生組合 } \\
\hline A 牛製品 & 843,105 & 427,550 & $50 \cdot 711$ \\
\hline B 轨道村料 & $2,282,641$ & $1,082,322$ & $47 \cdot 116$ \\
\hline C 型 銅 & $1,193,909$ & 259,272 & 21.715 \\
\hline $\mathrm{D}$ 全 $\mathrm{A}$ 生產品 & $4,319,655$ & $1,769,144$ & 40.956 \\
\hline 棒銅組合 & $3,895,829$ & $\mathbf{1 , 3 3 9 , 0 8 7}$ & $34 \cdot 372$ \\
\hline 粦鐵同盟‧ & 953,829 & 462,074 & $48 \cdot 444$ \\
\hline 板物組合 & $1,619,788$ & 721,640 & $44 \cdot 551$ \\
\hline 線材組合 & $1,540,896$ & 460,357 & 29.877 \\
\hline 針金製品組合 & 826,606 & 194,820 & $23 \cdot 569$ \\
\hline ロール粗合 & - & - & $50 \cdot 198$ \\
\hline
\end{tabular}

工場の改善及新設の煘の通常支出の外に本報告年度に於ては多くの新設エ事が完成せられた。重な るものを舉げればルールォルトに於ける電力分塊鋼片工場、アウグスト、チーセン、ヒュツテル於ける 塔鏣爐及製鋼工場並ドルトムンドニニオンの壓延工場の援張更にハムボルンのコークス製造所の完成 エリン及ミニスターシュタイン鋻坑の完成等である。

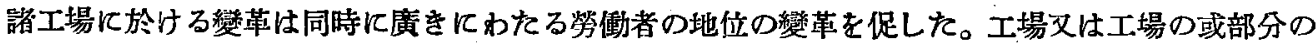
休止が寶行せられた結果そての勞働者は作業を繼續している工場に移動しなければならなかつた。し かしヌ多くの場合に於て解雇は避くべからさる所であつた。事務員や㕍員の側にも管理の變化、販賣 場の變化、帳簿の統一の結果非常な移動が必要とせられた。本營業年度の間を通じて全䯤に於て之を

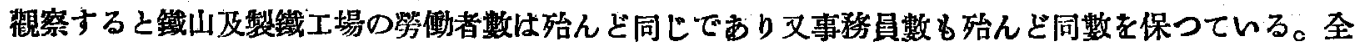


只數は年度の始に於ては 14,860 の事移且と 158,556 の学働者を包含していた。最初には使用人る淘 汰が行はれたのであるが少後再び塯加せられたので加盟各會塥の事務員及勞俨者は年度の終て於て各

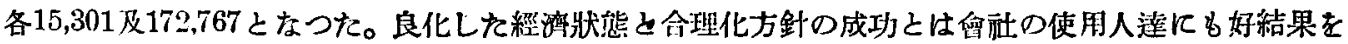

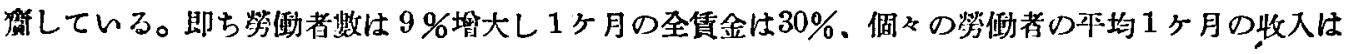

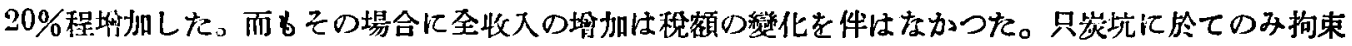

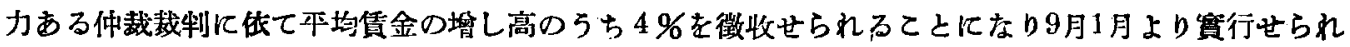

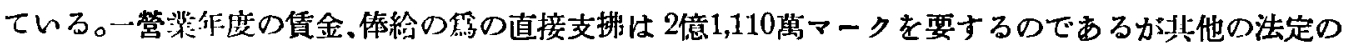
若くは自發的の負擔があり夫が全部で 2,200萬8,195 マークに達している。それ故に1年を通算すれば全

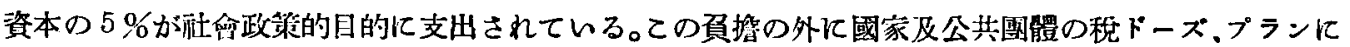

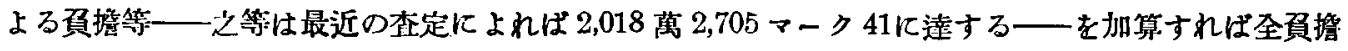
(42,190,500 マーク 41)は 1 年に於て株式資本10\%を越ゆるてとになる。ての非常に高をに上る㕵會的

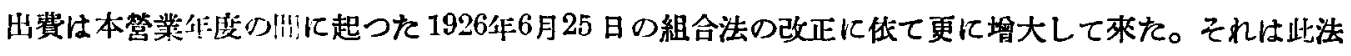
街が病人數を非常に堌加せしめたからである。何となれば病者支給規則はての法律に於て㱠んど勞働 貨余と同じ位の給付を約束した。そてで病氣の申出が堽加し炭山に於ける正常なる生産行程の遂行を 困難ならしめた。1人1月當りの病氣屆は鎐山に於て4月の1.51から9月の2.63と殆んど44.17\%增加した。 1926年9月30日貸偕對照表の財产其他の貸方は18億5,267 萬 1,425 マーク20である。眝座のちち主な

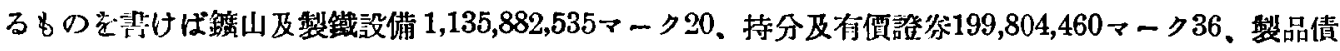
權269,681,147マーク74、借方のうちでは主なるものは袾式資本8億マーク、ゲヌスシャイン125,000,000 マーク．洗定積芒金79,994,000マーク、借入金402,754,000マーク、長期の倩務 $144,572,735$ マーク57。

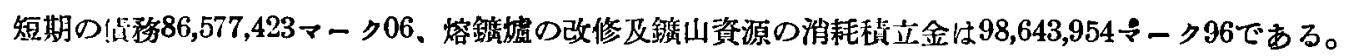
損益計算蓄㤌 $94,784,626$ マ - 320總收入を發表し其中加ら42,190,900マーク41の稅金、社會的出費 $26,136,370$ マーク79の各工場の減賈消却を差引いた挠純益を $26,457,355$ マーク12と計上している。此 の5ちから 6,000 マークが法定䅡，金とせられ 49,027.マーク10が定款による重役報酬として支拂はれ $24,000,000$ マーク (3\%) が利益分配、2,402,328マーク02が次期に繰连された。(三菱䌘鐵會䎟寄稿)

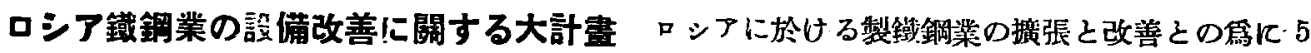
ケ年間にかたつて 3 億 5,000 萬弗を支出せんとする計畫は、最近に於てンヴイェツト政府と米國チカ

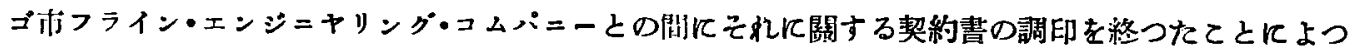
て、大に世人の耳目を衏動した。ロシアに於て彆鐵及製鋼工業を發達せしめんとする所以は、・ヴイエ

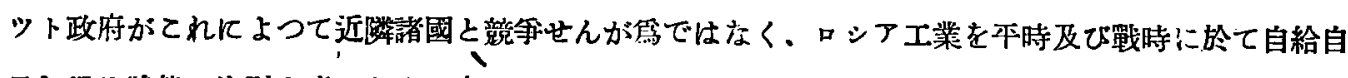
足し得る狀態に迄引_上げんとする處に外ならない。偝工業は政府の監督に虽し、一切つ競争を包避す ることに努めるであらう。

世界戰争前に於ては、ロシフの製鐵銅业は大部分外國資本の妾配するとてろであり，その目的とす， 


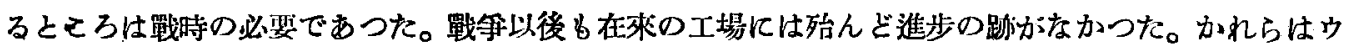
ラル地方に存在し、木炭をその燃料に使川してるた。今日に於ける生産は戰前の約70\%に到達してる る(註。ロシアの戰前1913年に於ける生产高红鉄鐵456英 3,000懒、鋼418萬1,000懒である)。

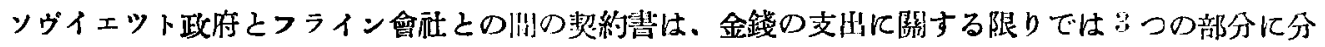

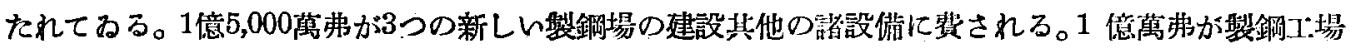

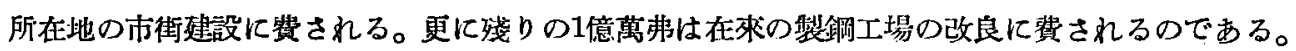

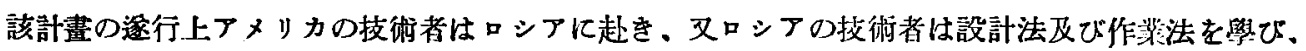

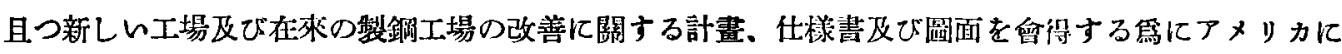
來るであらら。フライン會䎟は新工場の設計及び攺工場の現代化に關する計畫を作成するととになつ

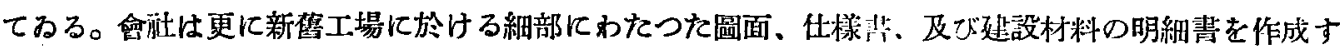
るであらら、しかしながらンヴイェット政府は、契約青のての部分の條項を其㿿筫行するか否かに關 する決定愯を保留する。契約害は更にフライン會融が工場の建設を監督すべきてとを規定してみる。

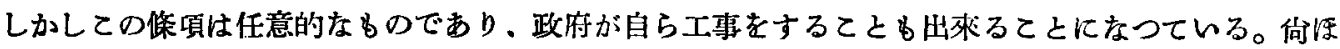
該契約書は、會社がその設計に參與しなかつた建設工事に對しては，會社はそれを監督する必要がな レと云ふととを熉定してるる。

報酬は建設緜算の額に從て一定のスライテングスケールに依り決定せられる。契約期間は 5 ケ年に 滿了し、ロシア政府性最初の3 年飞對して、建設が完成するかしないに拘らす、4,250 萬弗の事当: 損に相當する報酬を約東した。紛議を生じた場合に對しては契約書は調停候項を規定してるる。

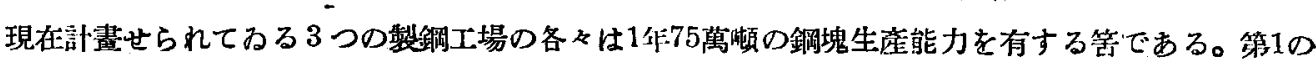
鯙定工場はアジア・ロシアを對象とし、シベリアのクズネッキー盈地飞建設せられる。その地點が選

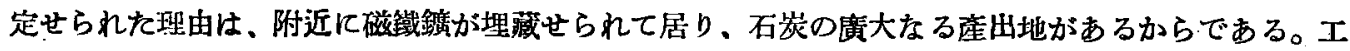
場はシベリア銭道の支線にそい、モスコウより東方1500マイル、支那の國境より北方 150 マイルの地點

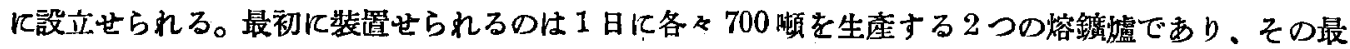
終の彩定生產能力の1/2亿相當するものである。

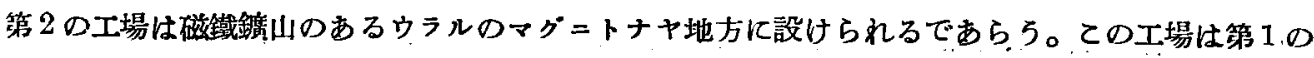
ものと同樣の生産能力を有する。第 3 ののは多分南ヨーロツヘ・ロシアのクリヴオイログに建設せら れる。そてには燐を多量に含む鐵鑛か灃富に埋藏せられており、且つ石岑の多量の供給が可能である。 良品質の石炭けウラル地方に於ては産出世られない。それ故に1500哩の遠方にあるクズネッキー盈地 から運搬する計畫がたてられてるるのである。

ロシア人は出來るだけ榙設備を統一世んてとを欲してるる。3つの新設借及び在來の工場のうち改 善せられる镍定のものは多くの默化於て同一の設備を探肘するであらら。

ロシアに於ける鐵銅業はすでての金屬の監督官廳たる金屬本部 (グラブ・タタル)の監督に屬する。 
ユージー・スタール・トラストとか南ロシア・ステール・トラストとかの藷トラストは金屬部の指揮の下 に立つてるる。数多の工場はてれらのトラストトの金下に集り。管轄上の品剩を形造つているのでする

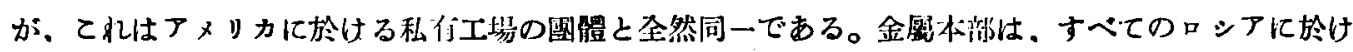

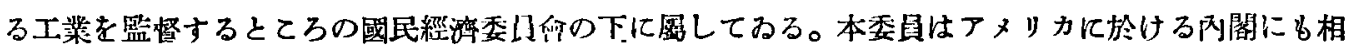

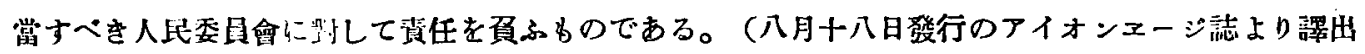
一三菱犁䥫寄稿)

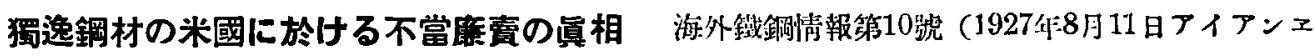
一流抄㩐)『政府當局の該事實に關する取調べに於て、獨逸オツトー、ウルフ商會米國代表大に誩朋

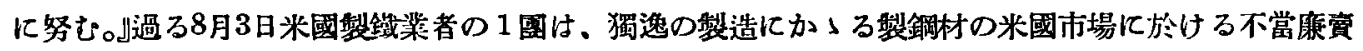

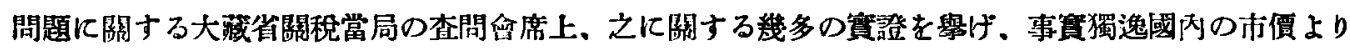

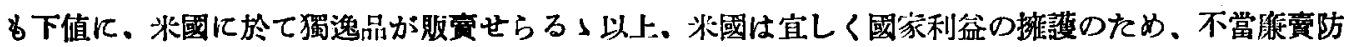
止法を適用すべしと，政府に要求する所があつた。

製鐵業者の陳述几對し輸入業者を代表せる摆逸オットー・ウルフ商會米國代表、ヂョージ、イー、

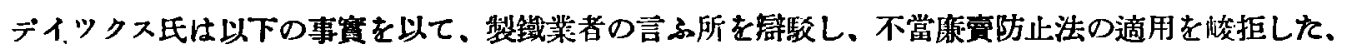

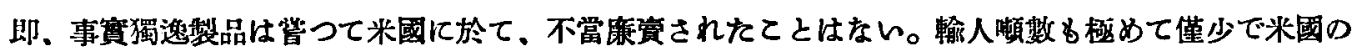

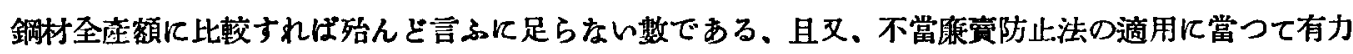

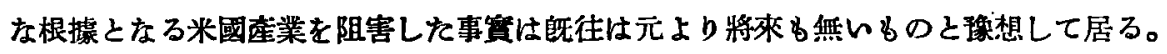

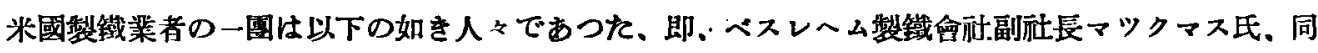
助手ヂョンストン氏、同社紐育建築肘賣主任ブレツトランド氏、同社ベスレへム販害技師マツキント ツシュ氏、同社菲府代表レオナード氏. ジョンス、ラフリン慗鐡組合輸出部支配人ホリデエー氏、ドン ネル製鐵所フイラデルヒフ販党部支配人フッブハウス氏、ホネーリング製鐵組合長助手フォツス氏、 ヤンク゚スタウン薄板、鋼管會行代售者助手フルヂェツチンガー氏、ビツツパーグ製鐵會社ミラー氏等

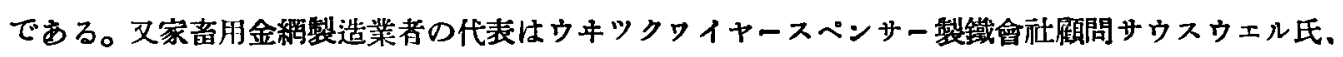
ホツト・ロールト・ストリツプ・インステイチュート顧問クラーク氏ですつた。

此间の事件の起因社、獨逸から海外に輸出す万製鐵並に鋼材には、同國政府が獎策金考與へて、保 護しておるといふ、告發に基くのである。米國大藏省當局は之に就て、獨逸に對し制止命令を出した。 そてで獨米から委員を出し、聯合委員會で調查して見ると、獎尉金を與へて居る證璩は一つつるないの で、米國は先の制止命令を撤回した。其の啳に至り法律の適用が不當源頡防止法の上に向けられ大藏 省關稅堂局が種々調查研究の未其を適用するてと〉なつた。元來不當廉賣法は。初め銑鐵について制 定されたもので。爾來今日に至つて居るめである。

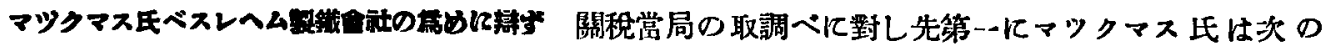
如く陳迅した。 


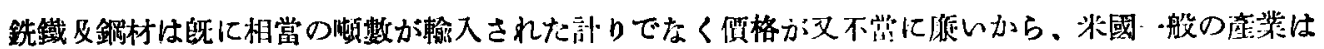

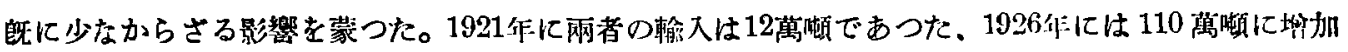

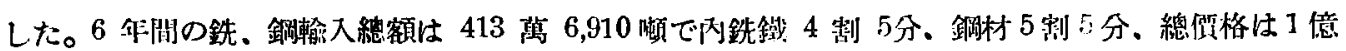

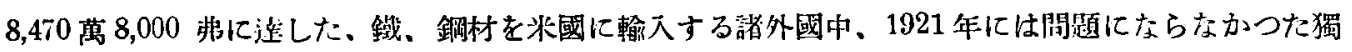
逸”、1926年に於て、一路第一位を占むるに至つた。们マツクス氏は、1927年2月3日版のアイアンエ ージ志を引用し陳逰をつげけた。

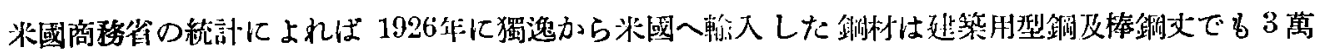

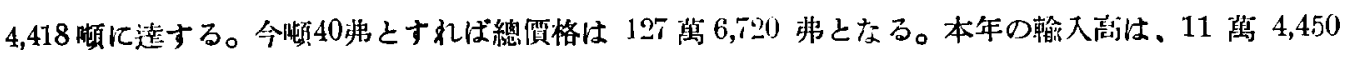

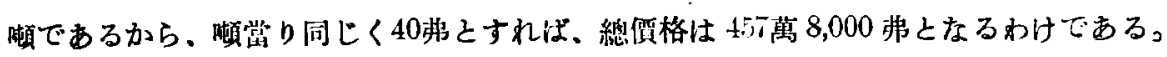

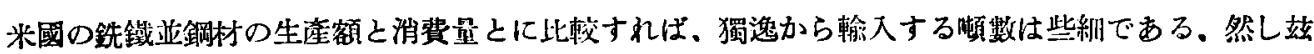

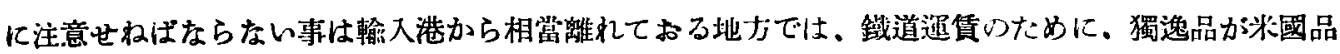

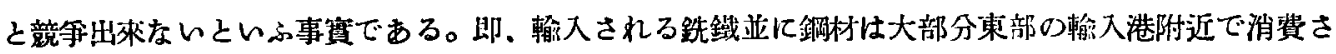

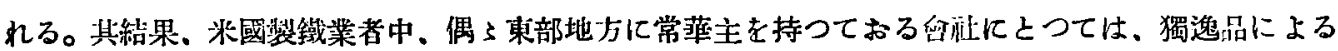

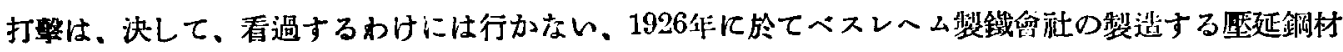

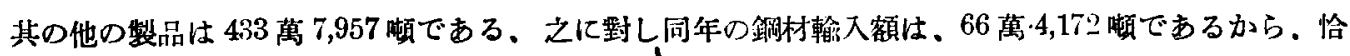

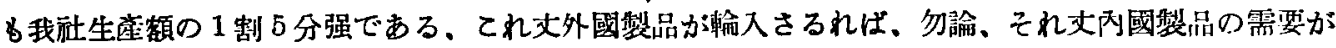
減るわけである、從つて我社の㹈品も確に啀迫を受けてるると信ずる。

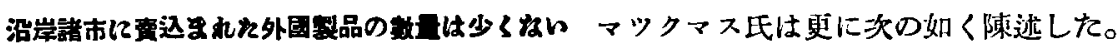

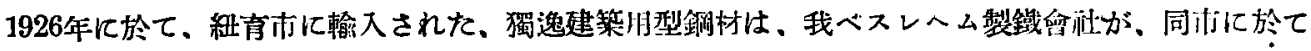
貶嘪する數量の、1割8分5重に相當したヌボストンオに輸入さるつ同種銅材は、我社の同才うに於ける

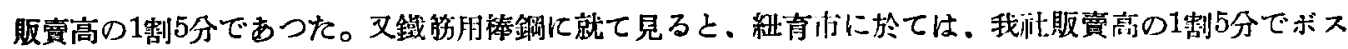
トンに於ては、我社販賣高の 3 倍以上になつてなつた。

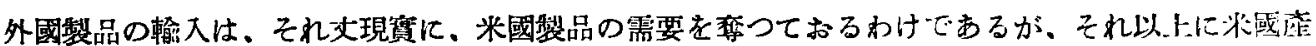

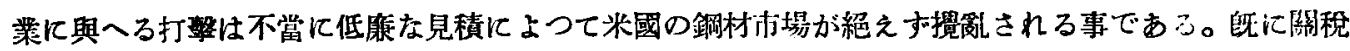

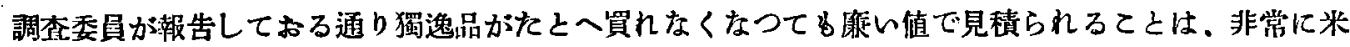
國の枋價を引下け゚るてと〉なるのである。

假に品質と納入保件とが同じならば、鋼材の注文は一番よい值段（即最低值）に出合ふか否か心よ

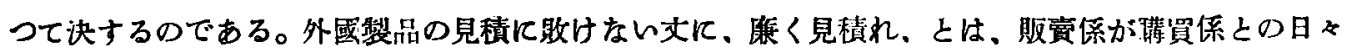

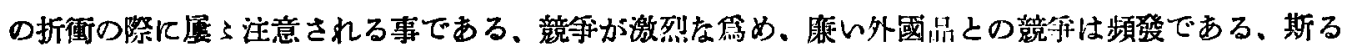

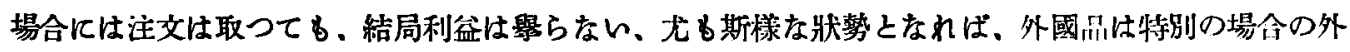
大概嘪れない，從つて輸入高が埥へるととはない。束に角、單に見猜のための不當に廉い外國の見積 は米國座筷にとつて大きい打軗である。 


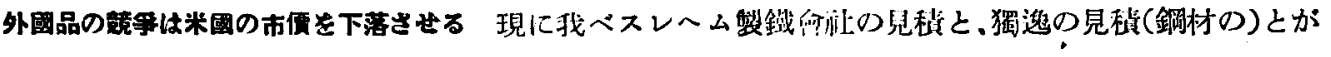

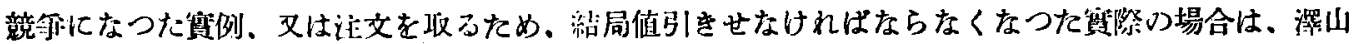

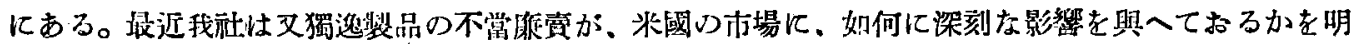

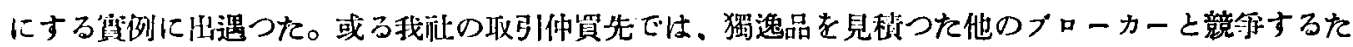

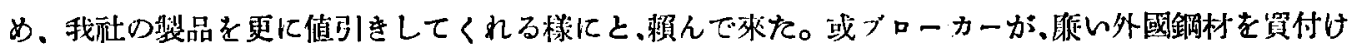
れば、他のプローカーは、それより除く、外國品を筫付けるか。さもなければ、內地品を値切る外。 仕方ないのである。

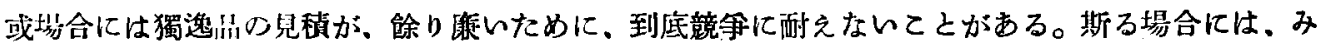

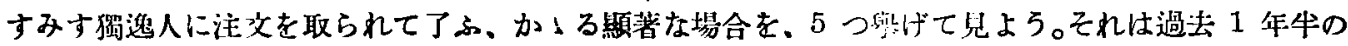

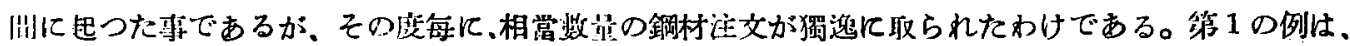

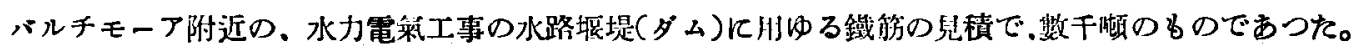

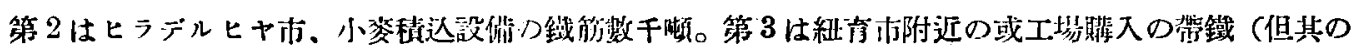
一部は米國品が探用された)。第 4 は、ミアミ附近のフロリダに於けるシートパイング材で、第 50

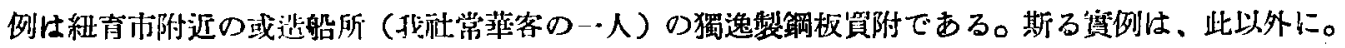
大西洋、太平洋兩岸に侣等山ある。

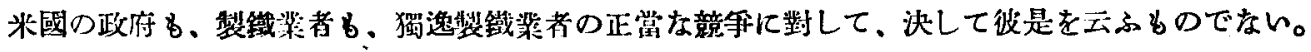

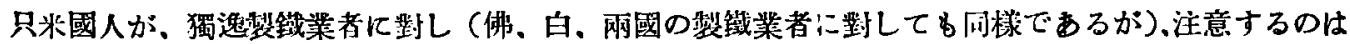

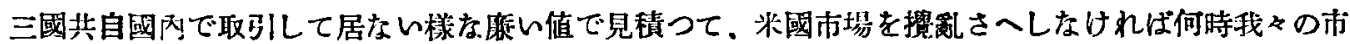
場に入つて來ても差支ないといふととである。米國に於ける嘪値が，自國に於けるものと同じ標集に さへあれ代、何等の制裁もなく單に普通の輸入國稅がかけらる」丈である。その率とても獨逸の現行 率より低く、重要製品で從價 1 割以下のものであるから決して輸入禁止的の重稅でない。

思ふに今日一，外國品の輸入は嫶加する一方で、且、二、歐洲諸國は、自給自足しておる米國の市

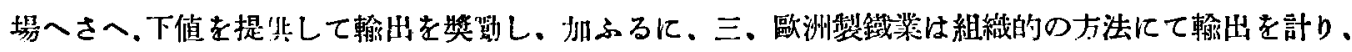

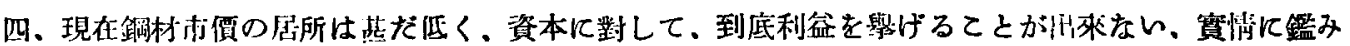

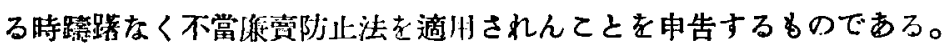

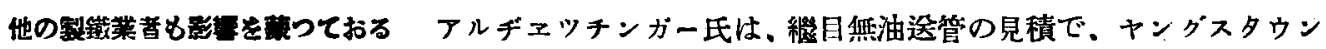
薄板鋼管會社が、太平洋岸地方で、獨䢠と湤しい競争に陷つたてとを指摘し、向次の如く述べた。獨

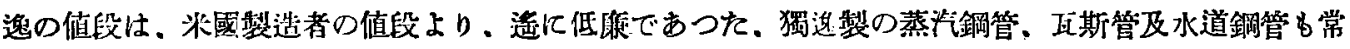

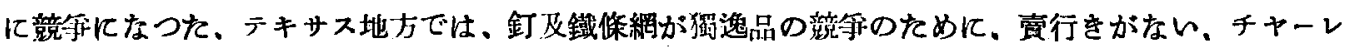
ストンを經由して多量の釷が輸入きれておる。

アップハウス氏の云ふのには昨年度に於ける、ドネル會䣓の生產噸数は減少した。乙れは獨逸品

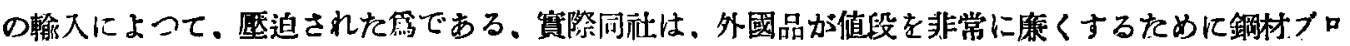


ーカーとの取引に困難しておる。

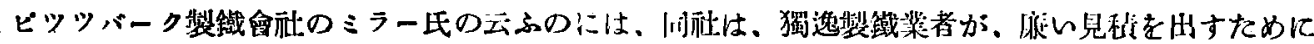

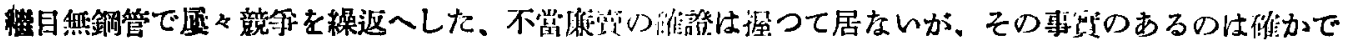

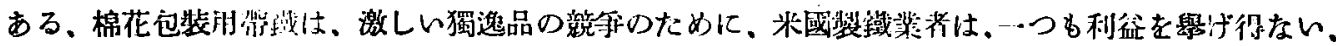

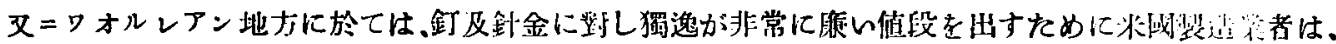

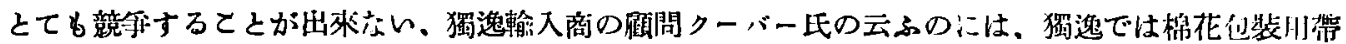

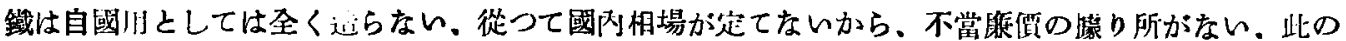

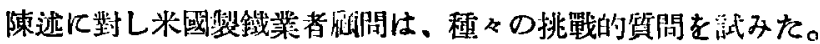

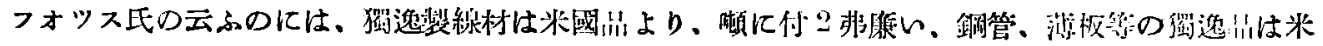

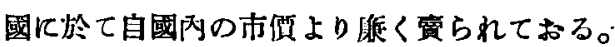

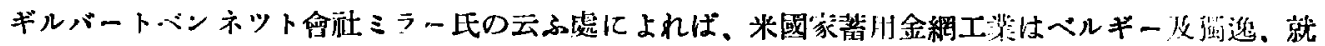

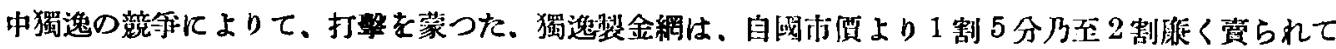
おる、その上、分颣の變更によつて國稅率を 4 割から2制 5 分に引下る運動さへ勝手に（使川考側に 於て) 努力さらておる。

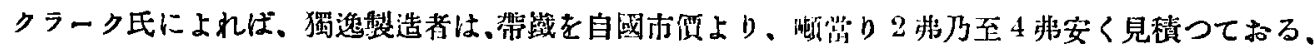

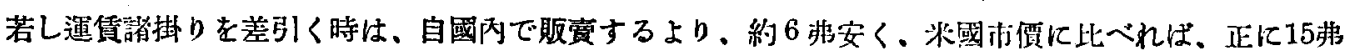
乃至20弗安いかけである。

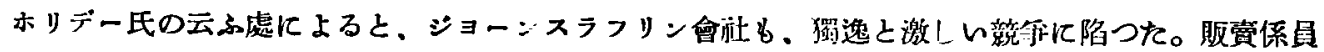

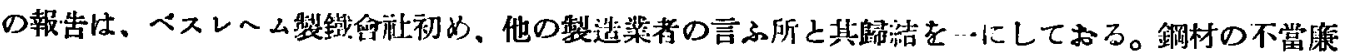

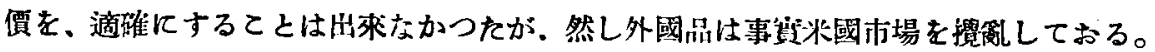

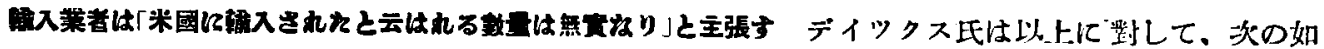
く高調した。即

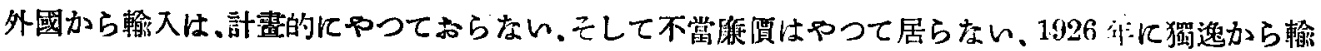

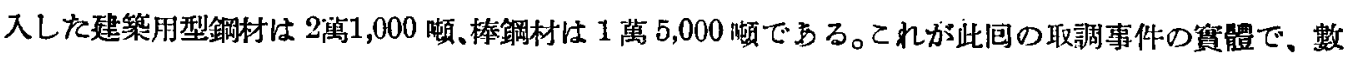

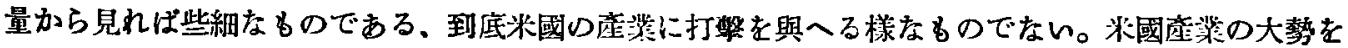

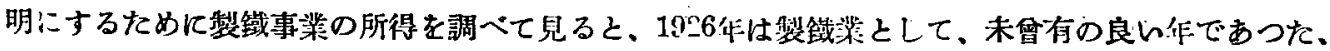

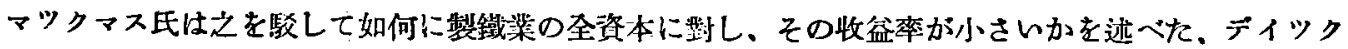
ス氏は1927年つ上牛期に、ウォルフ商會の手で、輸入した高仕 1 萬 6,500 顿で、ニー・エス・ニーホレ

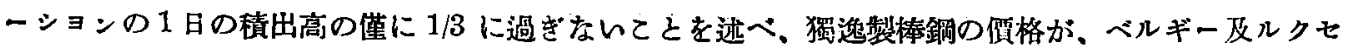
ンブルグに於ける見箐價格よりも高かつたてとをアイアンェーシ誌の引證によつて明にした。

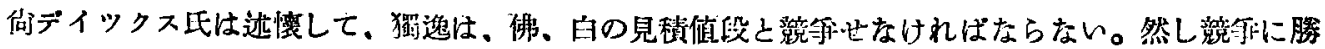
つた時は，不虽旗賞の奬疑を受ける時だと云つた。 
デイツクス氏仕更に二沃の事を逃べた。期

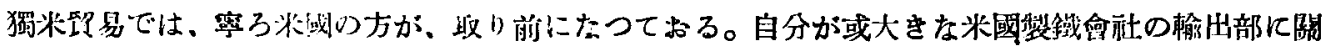

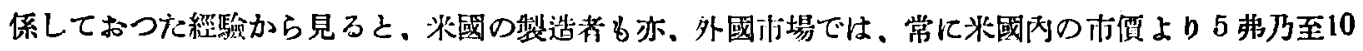

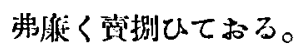

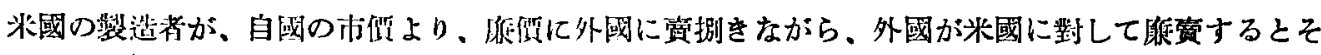
れを骩することの腬原をデイツクス氏が指摘した時に、理事官のカムプ氏は次の如く云つた。即。米

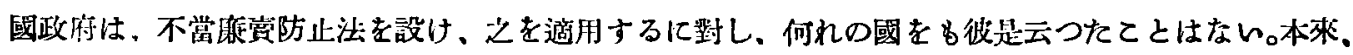
鋼材を犁造しない國に於ける場合と、无分に生產の姴素を借へておる國に於ける場合とでは、值段の

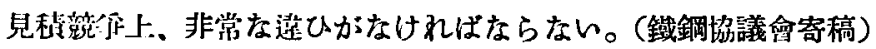

歐洲國際龬塊組合に對する米國の利害開係＼cjkstart海外鐵鋼情報第9號（DBZ紙 1927 年 8月18日制

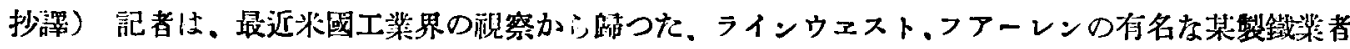

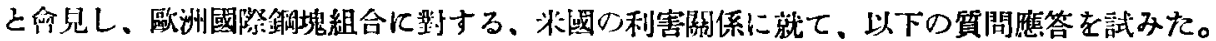

開（記者）近く米國は歐洲國绦銅塊組合に加盟するであら5か。

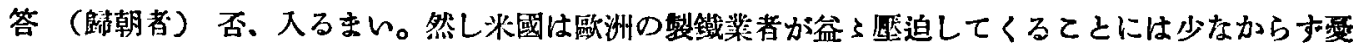

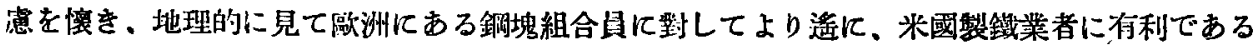
南米の市場に於ても、激しい競争が起るものと预期しておる。

問 國際鋼塊組合が成立した雼めに、米國の製鐵業が何か危險を感することはないか。

答 米國にとつて別段危險は無から5、然し英國が組合に加盟するてとになればその影響は免れまい

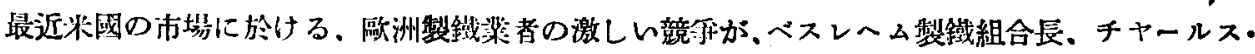
エム・シュワッブ氏によつて發表されたが、大變な評制である。

開 國際鋼塊組合に。米國が寥加しない理由は、單に米國のカルテル制度（外國の組合に加盟を禁止 せるもの) の䉆めであるか。

答 否.左様でない。一般米國人は若し國際銅塊組合一加盟することが米國にとつて必要となつた場合 には、カルテル法は决して邪魔になるものでないと、考へておる。加盟するか否かの問題は現 在の處それ程切迫しておらない。米國に於ては歐洲に於けるよりも一層廣沉に且有力に、作業及 技術上の集力整理か铱鐵業經嵤の上に筫行されて居るから此の點が米國の製鐵業にとつて强味

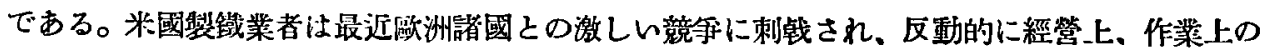
節約に努めておる。米國では特に高率の勞働賃銀が維持されて行かなければならないから一曆 その學悟を强くしておる。尤も高率なる勞䣦俥銀は米國市場の繁策を維持する一要素、換言す ればその下落は米國㧍場つ景氣を惡くするものと見做される。

問 生座の減退は米國內の市場に於ける購買力の㴻退に關係ありと見做して差支ないか。

答 それは勿諭閵係がある、就中、米國に於て最も大きい消费工柴であつて、數年柬生座制限をやつ 
ておる、自働車製造工業を考へて見る時に、それがよく判る。斯る事貝を見て考へんならんて

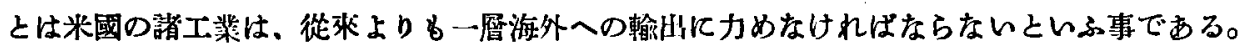
米國人が從來その方面に甚だ然頓着であつたととは世界の市場を見て选撼惩く證明さるっわけ である。

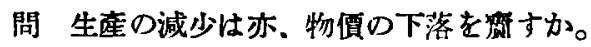

答 そうである然しそれはこく狭筑園でそ5であつて、銑鐵の如きものがその例である。

問 米國入が大に鐱出に努力した結果は鐵鋼材輸出の上に裴はれておるか。

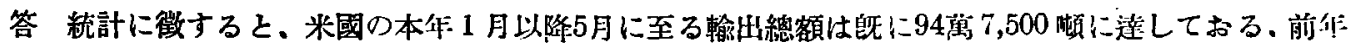
同期は87萬瀬であつた

問 米國の競争は歐洲にとつて閣題になるか。

答 問題と成るにはなるが。これも制限のある話で、例人ば英國の如きがそれである。若し英國が國 際鋼塊組合に加盟し且つ歌洲鋼管組合にも入る樣になればそそれは米國鐵鋼材の貶路に對し重 大な利害を持つてとにならら。

問 英國が本眞に、鋼管組合に入るものと、見て差支ないか。

答 此の點:就いての英國の交涉は最近大に進步した、然し暑中休㗇のために、昨今は停頓の姿であ る。大體交涉成行から見れば秋运には解決するだらら。最近の交涉は米國にとつて重大な利害 開係をもつておる。(鐵銅協議會寄稿)

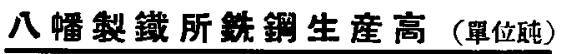

昭和 2 作 9 月中

”作累竐

前月比較

\section{銑 鐵}

54,044

526,526

$+\quad 372$
鋼 塊

82,477

781,465

$-\quad 3,318$
鋼 材

64,818

566,580

$+6,054$ 